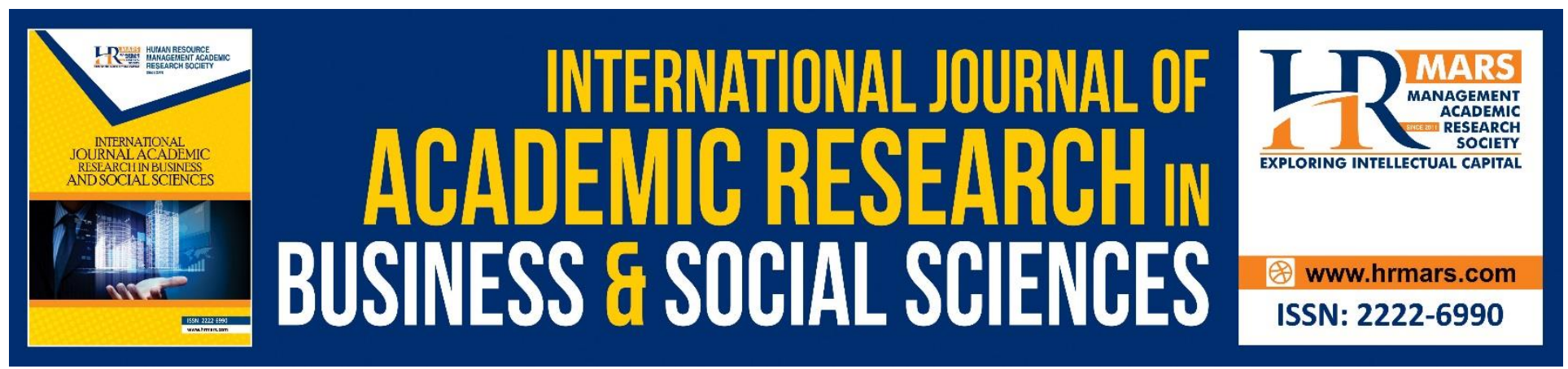

\title{
Ergonomics Kitchen: A Better Place to Work
}

\section{Faridah Hanim Ismail, Suriati Osman, Faradewi Bee A. Rahman}

To Link this Article: http://dx.doi.org/10.6007/IJARBSS/v11-i13/8501

DOI:10.6007/IJARBSS/v11-i13/8501

Received: 06 November 2020, Revised: 29 November 2020, Accepted: 19 December 2020

Published Online: 24 December 2021

In-Text Citation: (Ismail et al., 2021)

To Cite this Article: Ismail, F. H., Osman, S., \& Rahman, F. B. A. (2021). Ergonomics Kitchen: A Better Place to Work. International Journal of Academic Research in Business and Social Sciences, 11(13), 43-53.

Copyright: (C) 2021 The Author(s)

Published by Human Resource Management Academic Research Society (www.hrmars.com)

This article is published under the Creative Commons Attribution (CC BY 4.0) license. Anyone may reproduce, distribute, translate and create derivative works of this article (for both commercial and non-commercial purposes), subject to full attribution to the original publication and authors. The full terms of this license may be seen

at: http://creativecommons.org/licences/by/4.0/legalcode

Special Issue: Beyond 2021 and COVID-19 - New Perspective in the Hospitality \& Tourism Industry, 2021, Pg. 43 - 53

Full Terms \& Conditions of access and use can be found at http://hrmars.com/index.php/pages/detail/publication-ethics 


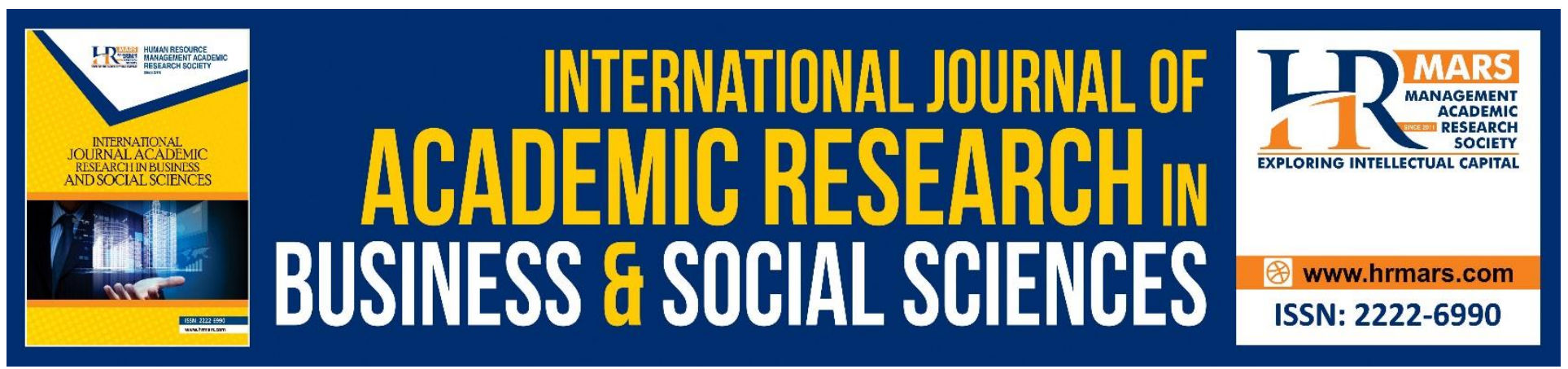

\title{
Ergonomics Kitchen: A Better Place to Work
}

\author{
Faridah Hanim Ismail, Suriati Osman, Faradewi Bee A. Rahman
}

Faculty of Hotel and Tourism Management, UiTM Cawangan Selangor, 42300 Bandar Puncak Alam, Malaysia

\begin{abstract}
Kitchen is a highly utilize space within a hotel and it is critical to practice ergonomic organization when operating at this area. Poorly planned kitchen layout affects the efficiency and productivity of daily operation, while causing physical hazards to operational employees in the long run. Due to the importance of maintaining employees' wellbeing, this paper aims to measure the awareness and the importance of practicing ergonomics among kitchen personnel in the hotel industry. Through quantitative research approach, a total of 27 kitchen personnel from different five-star hotels in Kuala Lumpur were analyzed. This study revealed that most respondents are aware about ergonomics and agreed that practicing ergonomics is essential to prevent fatigue at work. Limitations and propositions from this study are highlighted to guide future research. Overall, understanding the awareness and importance of practicing ergonomics is hoped to promote a safe and conducive work environment among kitchen personnel while nourishing existing literature relevant to ergonomics kitchen organization.
\end{abstract}

Keywords: Ergonomics, Standard -Design Kitchen, Ideal Measurements, Safety and Health, Work Fatigue and Productivity.

\section{Introduction}

The study of ergonomics has been extremely important in recent years. The spectrum of ergonomics has undoubtedly been discussed in sports, office workplaces and also in the service industry. The workplace is an important dimension that speeds up activity and puts minimal stress on employees. Therefore, the workspace needs to get a lot of attention in planning the layout. Given the importance of kitchen platforms, there is a need for kitchen design and ergonomic kitchen evaluation (Mahajan \& Patwardhan, 2015).

The word ergonomics became familiar and used and yet it was created due to the need to express scientific study (Carvalho \& Soares, 2012). Ergonomics is a scientific discipline as human factors related to the interaction between humans and other elements of the system, and professions that use theories, principles, data and application methods to optimize human well-being and the overall performance system (Middlesworth, 2020). This means that ergonomics can be defined as 
literally the study or measurement of work (Singleton, 2020). According to Carvalho and Soares (2012), the word ergonomic comes from the Greek word "ergon" which means work and "nomos" which means law. It is essentially "labour law" or "work science." Good ergonomic design eliminates incompatibilities between work and employees and creates an optimal work environment. In ancient Greek, cooperation doubled: slave labour, painful creativity and nothing (ponos) and works of creation, satisfaction and motivation (ergon). Therefore, the goal of ergonomics is to transform the pono into an ergon (Drury, 2000). However according to Pandve (2017) the original word ergonomic was first used in the philosophical narrative, in 1857 by Professor Wojciech Jastrzebowski of Poland. On July 12, 1949, Professor Hugh Murell formally proposed at a meeting of the British Admiralty, and in 1950 the word was accepted.

In this context, the term work indicates different human functions; it goes beyond the concept of more limited work as a workforce to generate income consistently, organization to achieve goals, this may include the example of domestic or non-domestic work, child care, the hotel industry, education, health and training centre, social services and etc. (Singleton, 2020).

\section{Literature Review}

This section deliberates on ergonomics with an emphasis on proposals and the development of a research framework.

\section{Knowledge}

Ghasemi et al (2005) stated that there was no significant link between knowledge of ergonomic principles and nurses' occupational health. These results can be interpreted as follows: when the work environment is not shaped by ergonomic principles, staff knowledge cannot be the only factor for success. Experts believe that the challenges posed by the lack of humanistic thinking in the design of work systems, because ergonomics have not been a condition in the life of the organization (Juibari et al., 2010). The majority are unfamiliar with ergonomics and its purpose, cumulative traumatic disorders, signs and symptoms, and risk factors (Sirajudeen et al., 2013).

\section{Work Fatigue}

Fatigue has been defined as the subjective experience of fatigue or lack of energy, normal fatigue is generally not experienced as an unpleasant state, as it can be disciplined by rest and sleep, so work-related fatigue has become an essential construct to understand the health and safety of employees (Rose et al., 2017). According to Nagai et al. (2011) the effect of fatigue at work subsequently influences a number of personal (physical, mental and behavioural, inability to relax) and organizational outcomes (attitudes at work, attendance and turnover; poor performance; work injuries). In addition, severe long-term fatigue can lead to sick leave and incapacity to work (Beurskens et al., 2000).

In the kitchen, the need to have everything on hand and to move freely and tirelessly is often the goal that is not achieved satisfactorily (Shete et al., 2015). Repetitive movements such as chopping and climbing vegetables, uncomfortable positions such as holding your head down to cook food or bending while arranging appliances, over-assaulting like reaching supplies on platforms or 
reaching higher cabinets, lifting like moving pots and pans are most commonly done while working in the kitchen (Shete et al., 2015). Its posture and maintenance play a major role in reducing muscle stress (Suhas et al., 2019).

This interest has increased in recent decades, as fatigue at work is seen as a personal and important work outcome that can link working conditions to employee health, work attitudes, safety and performance, for example, fatigue at work is the most important element of the cost reduction model (Demerouti et al., 2003; Frone \& Tidwell, 2015). Taking into account three distinct energy sources, it can be determined specifically: physical fatigue represents extreme physical fatigue and reduces the ability to perform physical activity during and at the end of the work day, while the mental fatigue of the work symbolizes extreme mental fatigue and reduces the ability to engage in cognitive activity experienced during and at the end of the work day (Frone \& Tidwell, 2015). However, ergonomic principles are not often taken into account in preparatory cooking, especially in developing countries (Singleton, 2020). Having a good environment in the kitchen provides a better environment such as good lighting, reducing noise contamination and proper temperature in the kitchen (Ramesh \& Manikandan, 2015). A good ergonomic plan in harmony between work and employees to form an optimal environment (Selamat, 2016).

The practice of ergonomics in the workplace helps organizations reduce health problems such as fatigue at work, improved body posture, muscle pain and work stress related to routine daily activities (Maguire et al., 2014). Stress at work and in time, rapid work rates and boring work are associated with musculoskeletal pain (Hoogendoorn et al., 2000).

\section{Safety and Health}

Workers in many different industries and jobs may be exposed to risk factors in the workplace, such as lifting heavy goods, bending overhead, pushing and attracting heavy loads, working in uncomfortable body postures, and performing similar or similar tasks several times (OSHA Publication, 2008).

The main root of injuries to kitchen members in addition to burns, slips and falls is back tension and tension in musculoskeletal disorders of underground carpal tunnel syndrome (Bhatia \& Singla, 2019).

According to Middlesworth (2020), the kitchen environment and kitchen parts play a strong role in the impact on workers' health. Author Middlesworth (2020) also states that workplace diets are not consistent with ergonomic principles, that they may be related to musculoskeletal disorders. Workplaces are an important aspect that accelerates activity and puts pressure on workers. This is one of the most important health problems encountered when working in the kitchen, seen a lot at the bottom and upper back (Sajida \& Chitra, 2014).

According to Maguire et al. (2014), the most common problems are realisation, slouching and stretching on the pelvis, access to the top shelves and bending on the lower shelves involve worker safety. The design of kitchen furniture that minimizes the unusual little kitchen activity is 
done by facing the walls, so that while working, employees can interact with others and do work without the difficulties (Shete et al., 2015).

\section{Perception}

Ergonomic perception can be achieved by gaining knowledge or training in this area (Koca \& Kaya, 2018). Ergonomics is known as a reconciliation between workload and labour in the best way to protect individual health and increase production (Ozturk \& Arici, 2018). In addition to implementing biological information in the fields of anatomy, physiology and experimental psychology, to replace the environmental system of human machinery (Genaidy et al., 2000). Ergonomics has been developed as a knowledge-gathering application in very different qualities that can improve the efficiency of human performance in different directions (Koca \& Kaya, 2018). As a personal area of work; ergonomics provides the necessary conditions for the adoption of "people" and "working" with each other, finding the characteristics and capabilities of human organisms (Koca \& Kaya, 2018). It allows people to be aware of their own abilities and to achieve them effectively. Ergonomics retains the individual so as not to be problematic due to extreme application while working to achieve success in the company (Koca \& Kaya, 2018).

The information seen by external organs of perception is to respond by actions in the central nervous system with the hands, arms and various organs of the human body. The success of this system is linked to the answers (Koca \& Kaya, 2018). The goal is to reduce discomfort and the risk of work-related injuries. In other words, employees are our top priority in the review of workstations (Antonioet et al., 2018).

The ergonomic improvement process in the workplace eliminates risk factors that lead to musculoskeletal injuries and improve human performance and productivity (Aqlan, Lam, Testani, \& Ramakrishnan, 2013). In the vagaries of the work process, the process will removing barriers to maximum safe work performance (Britoe et al., 2019).

\section{Productivity and Quality}

The ergonomics improvements improve quality and operator's productivity (Drury, 2000; Eklund, 1997; Kolus et al., 2018). Typically, ergonomic assessments are conducted by ergonomes, while workplace facilities are designed by planning engineers, and results are often unsatisfactory and do not increase productivity (Carey \& Gallwey, 2002; Gani, Zamberi, \& Teni, 2018). Improving efficiency and respect for cycle time, each workstation must undergo a one-minute, planned assignment time assignment, and a relative balancing/sequencing technique should be used in accordance with specific gatherings regarding the understanding of human interactions and other elements of the system, providing theoretical principles, data and methods for designing to optimize human well-being and overall system performance (Attaianese \& Duca, 2012)

\section{Awareness on Ergonomic in Kitchen Department}

In the context of operational workers, surprising awareness of ergonomics among the surgeons is lower (Modi, Kuswaha, \& Dave, 2013). So that; individuals gain awareness of their ergonomics and principles through properly designed education. The functioning of the respiratory 
system, circulatory system, muscle metabolism, digestive system, treatment system and nervous system of the human body at an adequate level is linked to the functioning process of the organs of good perception (Lundgren \& McMakin, 2018). The organization must take full responsibility for educating employees at a higher level by focusing on employees to practice manual handling ( $\mathrm{MMH})$ (Deros, Daruis, \& Basir, 2015).

\section{Methodology}

This study was conducted using a quantitative approach. An empirical study was conducted in an atmosphere that did not contribute to the use of individuals as adjustment units in the kitchen department of Deuce Restaurant and Majestic Hotels in Kuala Lumpur. Survey forms are provided to 30 employees using convenience sampling and distributed by email using Google doc support. Of the 30 surveys, 27 were returned and analyzed using the Statistical Package for Social Science (SPSS).

\section{Result and Analysis \\ Descriptive Analysis}

A total of 18 male and 9 female employees aged between 17 and 55 years of age participated in the study. 3 of them are Executive Chefs, 6 Sous Chefs, 8 Chef De Parties while the remaining are Commis. The highest qualifications were degree holders, followed by diplomas and Malaysian Certificate of Education (SPM) with 12, 5 and 10 respectively. All respondents worked at the hotel for 3 to 7 years. They usually work 8 to 10 hours a day. Respondents were asked three open-ended questions. Table 1 - 2 shows the questions.

Table 1: Open- ended question on staff experience of ergonomic

\begin{tabular}{cll}
\hline Question & Yes & No \\
\hline 1. Have you ever had any excessive fatigue while working? & 21 & 6 \\
2. Do you encounter problems with the space of your current workstation? & 19 & 8
\end{tabular}

According to the Table 1, 21 respondents experienced excessive fatigue while working and 6 of them did not. 19 respondents had experienced problems with their current workstation space and 8 of them had no problems with the workstation. 
Table 2: Open- ended question on problem encountered by staff

Question

Do you encounter any problems below?

1. No designated rack for utensil

2. Space of working area is too small

3. Distance between storage and working station is too far

4. Stoves are not at ideal placement
No. of

Respondent

3

8

6

2

Most respondents encountered similar problem of small walking space and a distance between the workstation and the storage room with a total of 8 and 6 respectively. 3 of the respondents encountered problems with the poor design of the utensil holder and 2 of the respondents agreed that the stoves were not in their ideal location. These problems contributed to the fatigue and well-being of staff.

\section{Analysis on Staff Knowledge and Perception About Ergonomics}

Each respondent was given a set of questionnaires to discover their knowledge and perception of ergonomics in the kitchen department. Based on the results of Table 3, most respondents agreed that ergonomic systems promote safety and health benefits to workers; and fatigue. Ergonomic systems help workers work efficiently, reduce fatigue, reduce movement while working, and improve overall restaurant flow during service. However, out of 27 respondents, only 15 are familiar with the ergonomics of the kitchen. Despite all of this, they agreed that ergonomics should be applied at their workplace.

Table 3: Analysis of staff knowledge on ergonomics

\begin{tabular}{|l|l|l|}
\hline Item & Yes & No \\
\hline I know about "kitchen ergonomic" & 15 & 12 \\
\hline The placement of kitchen appliances is important & 20 & 7 \\
\hline $\begin{array}{l}\text { The kitchen ergonomics systems help workers to work } \\
\text { efficiently }\end{array}$ & 18 & 9 \\
\hline $\begin{array}{l}\text { The kitchen ergonomic system brings advantages towards } \\
\text { workers }\end{array}$ & 22 & 5 \\
\hline Kitchen ergonomics system help workers to reduce tiredness & 15 & 12 \\
\hline $\begin{array}{l}\text { kitchen ergonomics system also adds safety features in the } \\
\text { kitchen }\end{array}$ & 18 & 9 \\
\hline $\begin{array}{l}\text { Kitchen ergonomic system help workers to reduce movement } \\
\text { while working }\end{array}$ & 20 & 7 \\
\hline $\begin{array}{l}\text { Kitchen Ergonomic system improve the entire restaurant flow } \\
\text { during service }\end{array}$ & 12 & 15 \\
\hline \begin{tabular}{l} 
Every kitchen should apply the ergonomics system \\
\hline I will apply ergonomics in my workplace
\end{tabular} & 27 & 0 \\
\hline
\end{tabular}


INTERNATIONAL JOURNAL OF ACADEMIC RESEARCH IN BUSINESS AND SOCIAL SCIENCES

Vol. 11, No. 13, Beyond 2021 and COVID-19 - New Perspective in the Hospitality \& Tourism Industry. 2021, E-ISSN: 2222-6990 @ 2021 HRMARS

Respondents were asked about their perception of ergonomics in the kitchen. 22 respondents agree that ergonomics in the kitchen is good for aging workers. They also agree that ergonomics in the kitchen increases productivity and quality of work such as reducing fatigue, organized workspace, proper operation, preventing accidents and minimizing the number of employees at a time. However, some of the respondents have an unbiased perception that ergonomics in the kitchen could reduce stress for workers. In general, most respondents agreed that kitchen ergonomics should be implemented in the workplace.

Table 4: Analysis of staff perception on ergonomics

\begin{tabular}{|l|l|l|l|l|l|}
\hline Item & $\begin{array}{l}\text { Strongly } \\
\text { Disagree }\end{array}$ & Disagree & Neutral & Agree & $\begin{array}{l}\text { Strongly } \\
\text { Agree }\end{array}$ \\
\hline $\begin{array}{l}\text { Kitchen Ergonomic is the key to a smooth } \\
\text { service run restaurant }\end{array}$ & - & - & 5 & 10 & 12 \\
\hline $\begin{array}{l}\text { Kitchen ergonomics helps to prevent } \\
\text { accident }\end{array}$ & - & - & 2 & 10 & 15 \\
\hline $\begin{array}{l}\text { Kitchen ergonomic gives less stress to the } \\
\text { worker }\end{array}$ & - & 2 & 15 & 5 & 5 \\
\hline $\begin{array}{l}\text { Kitchen ergonomics helps the cooks to be } \\
\text { much organized }\end{array}$ & - & - & 10 & 7 & 10 \\
\hline $\begin{array}{l}\text { Less worker would be possible to run a } \\
\text { restaurant }\end{array}$ & - & - & 5 & 15 & 7 \\
\hline $\begin{array}{l}\text { Kitchen would be much cleaner or easier to } \\
\text { clean }\end{array}$ & - & - & 12 & 11 & 4 \\
\hline $\begin{array}{l}\text { Kitchen ergonomics will boost up the } \\
\text { restaurant's profits }\end{array}$ & - & - & 10 & 10 & 6 \\
\hline $\begin{array}{l}\text { Kitchen ergonomics also good for aging } \\
\text { workers }\end{array}$ & - & - & - & 20 & 7 \\
\hline $\begin{array}{l}\text { Kitchen ergonomics help reduce work } \\
\text { fatigue }\end{array}$ & - & - & 6 & 15 & 7 \\
\hline $\begin{array}{l}\text { Every restaurant should implement the } \\
\text { ergonomics in the kitchen }\end{array}$ & - & - & 5 & 10 & 12 \\
\hline
\end{tabular}

\section{Conclusion}

In conclusion, researchers may deliberately conclude that understanding knowledge about ergonomics in the kitchen could bring safety and health benefits to workers, particularly excessive fatigue in the workplace. It is aligned with an earlier study that indicated that ergonomics could reduce fatigue, reduce movement and stress, and reduce workplace accidents (Frone \& Tidwell, 2015; Maguire et al., 2014). In addition, workers with a good perception of ergonomics will certainly agree that the practice of ergonomics in the kitchen will increase their productivity and quality of work (Attaianese \& Duca, 2012; Drury, 2000; Eklund, 1997).

In terms of limitation, future researchers could expand the scope of ergonomics not only in kitchens or restaurants, but also in other workplaces. Apart from that, future research could turn into 
INTERNATIONAL JOURNAL OF ACADEMIC RESEARCH IN BUSINESS AND SOCIAL SCIENCES

Vol. 11, No. 13, Beyond 2021 and COVID-19 - New Perspective in the Hospitality \& Tourism Industry. 2021, E-ISSN: 2222-6990 @ 2021 HRMARS

other dimensions such as economics and finance that could have advantages in the study of ergonomics.

\section{Acknowledgment}

Researchers like to thank Ahmad Aezriz bin Ahmad Kamil and Muhammad Syamil Nasriq bin Yusri, who graduated with a bachelor's degree in culinary and gastronomic management from the Faculty of Hotel and Tourism Management in 2014 for their contribution to this research article.

\section{Corresponding Author}

Suriati Osman.

Faculty of Hotel and Tourism Management, UiTM Selangor Branch, Puncak Alam Campus, 42300 Bandar Puncak Alam, Selangor, Malaysia

Email: Suria942@uitm.edu.my

\section{References}

Antonio, G. R. V., Sabanal, R. J. B., Baring, J. A., \& Sumadlayon, A. R. V. (2018). Ergonomic Practices in University of Cebu-Main Campus.

Attaianese, E., \& Duca, G. (2012). Human factors and ergonomic principles in building design for life and work activities: an applied methodology. Theoretical Issues in Ergonomics Science, 13(2), 187-202.

Aqlan, F., Lam, S. S., Testani, M., \& Ramakrishnan, S. (2013). Ergonomic risk reduction to enhance lean transformation. Paper presented at the IIE Annual Conference. Proceedings.

Beurskens, A. J., Bültmann, U., Kant, I., Vercoulen, J. H., Bleijenberg, G., \& Swaen, G. M. (2000). Fatigue among working people: validity of a questionnaire measure. Occupational and environmental medicine, 57(5), 353-357.

Bhatia, A., \& Singla, S. (2019). Ergonomic Evaluation and Customized Design of Kitchen. International Journal of Innovative Technology and Exploring Engineering, 8(9S), 10331039. https://doi.org/10.35940/ijitee.I1166.0789S19

Brito, M. F., Ramos, A. L., Carneiro, P., \& Gonçalves, M. A. (2019). A continuous improvement assessment tool, considering lean, safety and ergonomics. International Journal of Lean Six Sigma.

Carey, E., \& Gallwey, T. (2002). Evaluation of human postures with computer aids and virtual workplace designs. International journal of production research, 40(4), 825-843.

Carvalho, R., \& Soares, M. (2012). Ergonomic and usability analysis on a sample of automobile dashboards. Work, 41(Supplement 1), 1507-1514.

Demerouti, E., Bakker, A. B., Vardakou, I., \& Kantas, A. (2003). The convergent validity of two burnout instruments: A multitrait-multimethod analysis. European Journal of Psychological Assessment, 19(1), 12.

Deros, B. M., Daruis, D. D. I., \& Basir, I. M. (2015). A study on ergonomic awareness among workers performing manual material handling activities. Procedia-Social and Behavioral Sciences, 195, 1666-1673.

Drury, C. G. (2000). Global quality: linking ergonomics and production. International journal of production research, 38(17), 4007-4018. 
Eklund, J. (1997). Ergonomics, quality and continuous improvement conceptual and empirical relationships in an industrial context. Ergonomics, 40(10), 982-1001.

Frone, M. R., \& Tidwell, M.-C. O. (2015). The meaning and measurement of work fatigue: Development and evaluation of the Three-Dimensional Work Fatigue Inventory (3D-WFI). Journal of occupational health psychology, 20(3), 273.

Gani, A. Z., Zamberi, M. M., \& Teni, M. H. M. (2018). A Review of Ergonomics towards Productivity. Int. J Sup. Chain. Mgt, 7(4), 306.

Genaidy, A., Karwowski, W., Succop, P., Kwon, Y.-G., Alhemoud, A., \& Goyal, D. (2000). A classification system for characterization of physical and non-physical work factors. International Journal of Occupational Safety and Ergonomics, 6(4), 535-555.

Ghasemi, M., Menshadi, D. F., Soltani, A., \& Sheykhzadeh, H. (2005). Study of knowledge and performance of automobile workers about of health care for back bone. Journal of Health School and Health Research Institute, 3(9), 53-60.

Hoogendoorn, W. E., Van Poppel, M. N., Bongers, P. M., Koes, B. W., \& Bouter, L. M. (2000). Systematic review of psychosocial factors at work and private life as risk factors for back pain. Spine, 25(16), 2114-2125.

Juibari, L., Sanagu, A., \& Farrokhi, N. (2010). The relationship between knowledge of ergonomic science and the occupational health among nursing staff affiliated to Golestan University of Medical Sciences. Iranian Journal of Nursing and Midwifery Research, 15(4), 185.

Koca, E., \& Kaya, Ö. (2018). On Ergonomic Perception. In Advances in Physical Ergonomics and Human Factors, 403-410.

Kolus, A., Wells, R., \& Neumann, P. (2018). Production quality and human factors engineering: a systematic review and theoretical framework. Applied Ergonomics, 73, 55-89.

Lundgren, R. E., \& McMakin, A. H. (2018). Risk communication: A handbook for communicating environmental, safety, and health risks: John Wiley \& Sons.

Maguire, M., Peace, S., Nicolle, C., Marshall, R., Sims, R., Percival, J., \& Lawton, C. (2014). Kitchen living in later life: Exploring ergonomic problems, coping strategies and design solutions. International Journal of design, 8(1), 73-91.

Mahajan, S., \& Patwardhan, S. (2015). A study of ergonomic approach to kitchen work centers. Asian Journal of Home Science, 10(2), 371-374.

Middlesworth, M. (2020). Ergonomics 101_The Definition, Domains, and Applications of Ergonomics. Retrieved from https://ergo-plus.com/ergonomics-definition-domains-applications/

Nagai, M., Morikawa, Y., Kitaoka, K., Nakamura, K., Sakurai, M., Nishijo, M., . . Nakagawa, H. (2011). Effects of fatigue on immune function in nurses performing shift work. Journal of occupational health, 1107180194-1107180194.

OSHA Publication. (2008). Ergonomic for The Prevention of Musculosketetal Disorders.

Pandve, H. (2017). Historical Milestones of Ergonomics: From Ancient Human to Modern Human. J. Ergon, 7(4), 7556.

Ramesh, C., \& Manikandan, M. A. (2015). Thermal Analysis for the Ergonomics Design of Hotel Kitchen Environment. International Journal of Applied Engineering Research, 10(85), 2015.

Rose, D., Seidler, A., Nübling, M., Latza, U., Brähler, E., Klein, E., . . . Wild, P. (2017). Associations of fatigue to work-related stress, mental and physical health in an employed community sample. BMC Psychiatry, 17(1), 167. 
Sajida, S., \& Chitra, P. (2014). The ergonomic perspective of the homemakers in using kitchens. Asian Journal of Home Science, 9(1), 25-28.

Shete, K., Pandve, H., \& Puntambekar, T. (2015). Role of Ergonomics in Kitchen Related Back Problems. Journal of Ergonomics, 5(3), 1000e1141.

Singleton, W. T. (2020). Ergonomics [Chapter 29] (4th ed., pp. 1-109).

Sirajudeen, M. S., Pillai, P. S., \& Vali, G. M. Y. (2013). Assessment of knowledge of ergonomics among information technology professionals in India, 20(29), 135.

Suhas, M., Prajapathi, P., Jolhe, D., \& Lakhe, R. (2019). A study of Indian kitchen from ergonomic consideration. Industrial engineering journal, 12.

Öztürk, D., \& Arici, Y. K. (2018). A Study on Workplace Environment Ergonomics and Conditions of Employees in Rice Factories. Business Studies, 41.

Selamat, M. (2016). Ergonomic Work System and Occupational Safety and Health Performance: Mediating Effects of Psychosocial Work Factors. Universiti Sains Malaysia, 62(1), 27-40.

Shete, K., Pandve, H., \& Puntambekar, T. (2015). Role of Ergonomics in Kitchen Related Back Problems. Journal of ergonomics, 5, 1000e1141. 